\title{
FRED G. BARD, NATURALIST AND CONSERVATIONIST
}

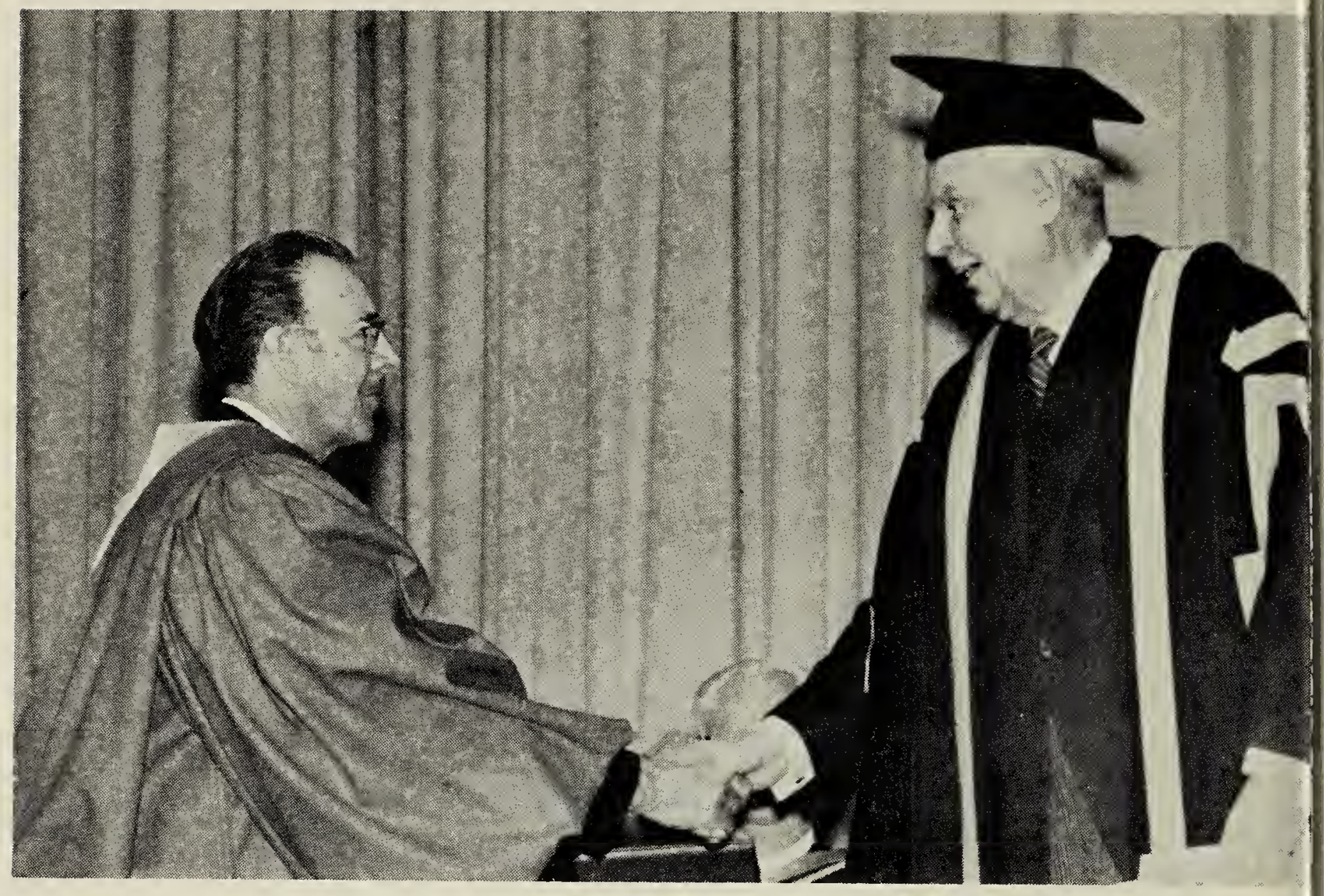

Photo courtesy University, Regins

On May 15, 1970, the University of Saskatchewan Regina Campus conferred an honorary doctor of laws degree on Fred G. Bard, former director of the Museum of Natural History in Regina. Though he held the position of Museum director from 1947-1970, Mr. Bard worked at the Museum for a total of forty-five years, years which saw the Museum begin to expand, experience the turmoil of the war years and finally achieve the construction of a permanent building - a building which in itself is a graphic testimonial to his imagination and energy. The dioramas at the Museum, unique of their kind, show his regard for scientific accuracy and his appreciation of artistic excellence. During these fortyfive years Mr. Bard occupied himself not only with the various activities which a museum position demanded of him but also in becoming expert concerning two specific programs-the reestablishment in Southern Saskatchewan and adjoining regions of the
Canada Goose (by means of a special project on the Wascana marsh) and the effort to preserve the Whooping Crane from extinction. Now, though he has retired from active participation. in museum work, Mr. Bard has no intention of abandoning his main interests. For he sees that in a sense the problems facing these two species epitomize the problem which confronts all living creatures. That problem concerns the inability of man (or at least the inability of modern man) to understand that

"All are needed by each one;

Nothing is fair or good alone."

It is Mr. Bard's belief that modern man, who has become physically and spiritually urbanized, has no conception of the value of quiet. This in turn makes him heedless of the fact that the destruction of the quiet wilderness areas of the world will destroy that life which requires quietness for survival. The aspect which materially-minded man does not appear to appreciate is 
that the destruction of the balance in nature, the refusal to recognize that all living things are part of the whole, will in the end lead to his own extinction.

But Mr. Bard does not speak in generalities only. He relates the global problem to the one which for so many years has been closest to his handthe problem of the Wascana marsh. The complex marsh environment is, he believes, the most fascinating in the world but, because it is usually unspectacular from the scenic standpoint, the least understood. Added to this lack of understanding is the short-sighted tendency to overemphasize the importance of agricultural development, a tendency which results in the draining of marsh lands. Excessive draining cannot but have a detrimental effect on those marshes which, for one reason or another, have been retained. The Wascana marsh is a good case in point.

If the Wascana marsh is to be preserved and the projects (especially those relating to the Canada Goose) are to thrive, a long-term, clearlydefined policy must be formulated. According to $\mathrm{Mr}$. Bard, many officials who are currently interested in conservation think only in terms of immediate action relating to minor problems. Government authorities must become aware that long-term programs which involve the inevitable expenditure of large sums of money are not luxuries but necessities. And such programs, ooth in relation to museum work and research and to environmental preservation, must be planned and implemented by people possessing precise, cientific knowledge. A vague kind of coodwill and a "good public relations" attitude are equally ineffectual. We have reached a stage in the destruction if our environment which necessitates lefinite scientific control. (The recent orest-fire threat in northern Alberta made clear that Whooping Crane nests nust be placed in several locations if the birds are to survive.)

Mr. Bard has many specific proosals to make concerning the Wasana marsh. That view of the area which emphasizes the importance of landscaping and "beautifying" is essentially, he feels, a superficial one. It is obligatory to preserve the natural environment of the marsh in order to maintain habitat requirements. Islands must be built, tributaries dammed, native plants introduced, sections zoned for scientific control projects. If such control measures were employed, $\mathrm{Mr}$. Bard envisages possibilities for the introduction of many new species: Snow Geese, for example, could be grounded in the Wascana marsh and possibly wintered at Ipsco; waterfowl could be brought in for display ponds; Tree Swallow nests could be introduced. In other words, the "beautifying" urge would be satisfied at the same time as the broader conservation aim would be achieved.

The ordinary citizen, too, must be taught a willingness to be guided by expert opinion. If the Department of Natural Resources were to embark on a concentrated informational program - by means of publicized research studies and films and lectures designed to stimulate an appreciation of our wildlife inheritance - the general public, both children and adults, would recognize the importance of governmental and individual responsibility. (A child, after all, does not understand that disturbing colonial birds at nesting-time can have disastrous results unless someone informs him of the fact.)

Those who have worked in the field with Fred Bard invariably comment on his ability to transmit to others both a sense of excitement and an urge to act. In the words of Dr. L. Greenberg, who presented him to the Chancellor of the University for his degree: "Mr. Bard is a man who does things; he does not just talk." I return, therefore, to my earlier statement concerning his future. Fred Bard has retired as Director of the Museum of Natural History. It is unthinkable that he should retire from the struggle for conservation and particularly the struggle for conservation in Saskatchewan.Jeanie Wagner, Regina. 